\title{
Social and Solidarity Economy and the need for its entrepreneuring ecosystem: current challenges in Brazil
}

\author{
Leandro Pereira Morais \\ Miguel Juan Bacic
}

ABSTRACT: This article's purpose is to discuss the state of the art of the constitution of the entrepreneurial ecosystem for SSE and its application in Brazil. One of the major challenges for the creation, continuity and strengthening of Solidarity Economy Enterprises (SEE) is the effective establishment of an entrepreneurial ecosystem for Social and Solidarity Economy (SSE). The construction of the solidary entrepreneurial ecosystem is a complex task, full of challenges, especially when this construction is associated to structural weaknesses inherent to its modus operandi. Case studies of several countries allow us to define general guidelines for the application of public policies that show paths in this direction. Considering this, we organized the article as follows: After the Introduction, we discuss some aspects of the entrepreneurial ecosystem, in topic 1. Then, topic 2 presents the idea of the "triple helix" and coevolution among the elements of the ecosystem and enterprises. Next, topic 3 addresses the construction of the entrepreneurial ecosystem for SSE in some countries in Europe and Asia. Finally, in item 4, some considerations about the Brazilian case.

KEYWORDS: Solidarity entrepreneurial ecosystem, Social and solidarity economy, Solidarity Economy Enterprises, Co-evolution.

ECONLIT DESCRIPTORS: 015.

How to cite this article: MORAIS, L.P. \& BACIC, M.J. (2020): "Social and Solidarity Economy and the need for its entrepreneuring ecosystem: current challenges in Brazil", CIRIEC-España, Revista de Economía Pública, Social y Cooperativa, 98, 5-30. DOI: 107203/CIRIEC-E.98.14138.

Correspondence: Leandro Pereira Morais, Department of Economics of UNESP-Araraquara, Brasil, E-mail: Ipmorais@fclar.unesp.br, and Miguel Juan Bacic, Institute of Economics of University of Campinas, Brasil. E-mail: bacic@unicamp.br. 


\section{RESUMEN AMPLIO}

\section{La Economía Social y Solidaria y la necesidad de un ecosistema emprendedor desafíos actuales en Brasil}

\section{Contextualización y objetivos del trabajo}

En Brasil y en varios países, la Economía Social y Solidaria (ESS) se viene presentando, en los últimos años, como una innovadora alternativa de generación de trabajo e ingresos y una respuesta a favor de la inclusión sociolaboral. Para muchos puede ser considerada también como un nuevo modelo de desarrollo, más humano, inclusivo y sostenible.

La ESS comprende una diversidad de prácticas económicas y sociales, que realizan actividades de producción de bienes, prestación de servicios, finanzas solidarias, intercambios, comercio justo y consumo solidario, etc. La ESS presenta un carácter transversal, o sea, puede movilizar diferentes áreas de la acción pública y social, ya que puede contemplar, en sus acciones, objetivos económicos (generación de trabajo e ingresos), sociales (mejora en las condiciones de sociabilidad y fortalecimiento de los lazos territoriales), políticos (creación de espacios públicos para analizar, discutir y resolver problemas), culturales (nuevos patrones de producción y de consumo) y ambientales (reeducación ambiental a favor de la sostenibilidad).

La ESS no se trata solo de un problema económico, ya que puede involucrar otras cuestiones tales como la sociabilidad en los territorios, la participación política de las personas, el grado de organización asociativa, la preservación ambiental, la afirmación de identidades culturales, etc.

Sin embargo, a pesar del potencial de la ESS, se pueden observar debilidades de orden estructural que contemplan aspectos económicos, financieros, jurídicos, contables, de acceso al crédito, al mercado y a las nuevas tecnologías, de cualificación de la mano de obra, etc.

En este sentido, se entiende que uno de los grandes desafíos para la creación, el mantenimiento y el fortalecimiento de las Empresas de Economía Solidaria (EES) es el establecimiento efectivo de un ecosistema emprendedor para la ESS. Se cree que la formación del ecosistema emprendedor para la ESS es fundamental para la emancipación de las EES. Cabe señalar que uno de los principales problemas de las EES es que la construcción del espacio emancipador o del espacio de autonomía tiene como requisito previo habilidades y recursos que no están al alcance de la mayoría de las personas que participan en estos emprendimientos. Por esta razón, no es posible una copia pura y simple de las instituciones que operan dentro del ecosistema emprendedor de las empresas tradicionales, al considerar la articulación de un conjunto de instituciones y actores que actúen a favor de la ESS, 
ya que las EES poseen características específicas, con implicaciones socioeconómicas, políticas y culturales en sus territorios, diferentes de las que se pueden encontrar en las empresas tradicionales.

Así, el objetivo de este artículo es discutir el estado del arte de la construcción del ecosistema emprendedor para la ESS, dado que la formación de este "ecosistema" es un instrumento fundamental para la emancipación y el fortalecimiento de las EES. La construcción del ecosistema emprendedor solidario es una tarea compleja, marcada por muchos desafíos, particularmente cuando esta construcción está conectada a debilidades estructurales inherentes a su modus operandi.

\section{Consideraciones metodológicas}

Estudios acerca del ecosistema aplicado a la ESS constituyen un tema en construcción y de relativa complejidad, teniendo en cuenta algunas lagunas aún existentes, que se refieren al desafío de definir y desarrollar metodologías e instrumentos de investigación capaces de captar, empíricamente, las conexiones de la "dinámica innovadora local", marcada por "interacciones locales", que abarcan aspectos económicos, sociales, políticos, culturales, socio institucionales, etc. En otros términos, "la comprensión de estas complejas relaciones plantea nuevas preguntas en los campos conceptual y metodológico, exigiendo instrumentos capaces de verificar y evaluar los procesos del dinamismo socioeconómico local" (Albagli \& Maciel, 2004: 12).

En este sentido, las autoras proponen, como parámetros de investigación empírica, dos grandes grupos de estudios: i) estudios de casos (presentando descripciones detalladas sobre estos procesos) y ii) estudios estadísticos. En este trabajo, se optó por el primer grupo, para lograr el objetivo de comprender la dinámica de construcción del ecosistema emprendedor solidario para el caso brasileño.

La opción por esta estrategia es interesante para los objetivos de la construcción de este trabajo porque asegura la flexibilidad necesaria para la investigación exploratoria, al mismo tiempo que nos permite organizar la investigación en torno a los constructos de interés (Gil, 2008).

Al ser un estudio exploratorio, de naturaleza cualitativa, este artículo pretende responder al problema propuesto a través del detalle de informaciones no cuantificables en este momento, como la identificación de los principales actores responsables por las "interacciones locales" en la construcción del ecosistema emprendedor solidario, así como sus conexiones e influencias en la concepción de políticas públicas nacionales de ESS.

Por lo tanto, este trabajo utiliza una revisión de la bibliografía acerca de la temática en cuestión, ya sea en ámbito internacional (con énfasis en los casos europeos y de Corea del Sur), o sea en ámbito nacional (Brasil). La revisión bibliográfica internacional nos auxilió en la composición de una estructura analítica y descriptiva para pensar en la elaboración del ecosistema brasileño, aún en construcción (o, actualmente, en deconstrucción). 


\section{Principales resultados, límites y consideraciones finales de la investigación}

La formación del ecosistema emprendedor para la ESS en Brasil - un tema aún en construcción, lo que, incluso, puede revelarse como un factor limitante en la investigación, debido a la relativa ausencia de material sobre el tema - es una parte fundamental para la emancipación y el fortalecimiento de las EES, teniendo en cuenta las debilidades estructurales inherentes a su modus operandi.

En este sentido, se entiende como una estructura coherente de organización del proceso ecosistémico emprendedor solidario, los siguientes componentes: a) Conocimiento; b) Acceso a los mercados; c) Soporte público y fiscal para start-ups de ESS; d) Acceso al financiamiento; e) Instrumentos de apoyo a las redes y soporte mutuo y f) Desarrollo de investigación y cualificación en el área. Se reitera que es importante incluir en esta estructura la capacidad de crear indicadores de evaluación y monitoreo de las EES; tarea ardua y compleja, pero de extrema relevancia para evaluar las políticas relacionadas con la ESS, así como sus impactos en los respectivos territorios de acción.

Más allá de esta estructura de composición ecosistémica, vale enfatizar el papel fundamental de las EES y de la universidad en la coconstrucción de la política pública para la ESS. Además, se cree que mantener el liderazgo del ecosistema dependerá de la capacidad de convencimiento de sus actores de que vale la pena continuar evolucionando juntos, es decir, coevolucionando. En otros términos, la vitalidad colectiva (y no individual) del ecosistema es una condición para su propia sostenibilidad, mantenimiento y evolución. En lugar de centrarse únicamente en sus competencias, recursos y capacitaciones internas, los involucrados deben saber de las interdependencias entre los organismos del ecosistema y enfatizar las propiedades colectivas de las redes de EES.

De ahí deriva que otro elemento fundamental de la construcción ecosistémica es el grado de interconexión, de interdependencia que todos los componentes del sistema guardan entre sí, así como la necesidad de la construcción de un proceso que se debe permear por una perspectiva "bottom-up" y de transversalidad, posibilitando la coevolución hacia una "vitalidad colectiva" y con grados de interconectividad entre las partes.

En términos prácticos, ya hay ejemplos en algunas partes del mundo que parecen ser de interés, como los casos de Europa y Corea del Sur, presentados en este trabajo. En lo que concierne al caso brasileño, a pesar de las potencialidades y los avances en la ESS en Brasil, se percibe que este "sector" está marcado por determinadas fragilidades, así como las referidas a lo largo del trabajo. Dichas debilidades se sitúan fundamentalmente en: a) debilidades microeconómicas: condiciones del mercado (oferta y demanda de los productos y servicios), fijación de precios y de costos productivos, condiciones de comercialización, acceso a la tecnología, al capital de giro de las ESS, etc.; b) fragilidades macroeconómicas: condiciones más generales del funcionamiento de la economía y de la exclusión de determinados grupos de acceso al crédito en condiciones facilitadas; tasa de interés elevada; impactos del ajuste fiscal en la continuidad de programas, proyectos y acciones, etc., y c) políticas pú- 
blicas de apoyo: la falta de acciones integradas y transversales (entre ministerios, secretarías, etc., en los ámbitos federal, estatal y municipal) que disminuyen los posibles avances en pro de los objetivos de generación de trabajo, empleo e ingresos y de la propia existencia de diversas experiencias. Esto también se debe a la falta de claridad en lo que concierne a la definición y mensuración del "sector".

La existencia y el fortalecimiento del ecosistema emprendedor solidario son un aliado importante en el enfrentamiento de estas fragilidades intrínsecas a la ESS.

Como esta es una investigación basada en la revisión de la literatura y los estudios de casos, las conclusiones dependen de la bibliografía que se ha estudiado. Nuevos estudios de caso con resultados diferentes pueden afectar las conclusiones de este trabajo. Por otro lado, creemos que la bibliografía utilizada es lo suficientemente sólida y amplia como para mostrar la importancia que las políticas públicas deberían dar a la conformación de un ecosistema empresarial solidario para las EES.

PALABRAS CLAVE: Ecosistema emprendedor solidario; Economía Social y Solidaria, Empresas de economía social y solidaria, Coevolución. 


\section{Introduction}

One of the greatest challenges for the creation, maintenance and strengthening of Solidarity Economy Enterprises (SSE) is the effective establishment of an entrepreneurial ecosystem for Social and Solidarity Economy (SSE). We understand that the formation of the entrepreneurial ecosystem for SSE is a fundamental tool for the emancipation of Solidarity Economy enterprises (SSE) (Morais \& Bacic, 2016). One of the greatest problems observed in SSE is that the construction of the "emancipating space" or the "space of autonomy" demands skills and resources that are not available to the majority of people who participate in self-managed groups. This statement does not imply that we believe there is an automatic passage from the circumstances that surround the entrepreneurial ecosystem, in traditional companies, to those of SSE, since these have characteristics that are inherent to their modus operandi, with particular socioeconomic, political and cultural implications in their territories (Morais, 2013; Bacic, 2014; Barquero, 2018).

On the other hand, we can observe a certain resistance - real, symbolic or even ideological - to discuss issues that are more strictly economic and financial, such as production costs, loan costs, market strategies, surplus production, etc.

According to Gaiger (2008), intellectuals who discuss SSE do have these resistances. An example is the resistance to discussing issues related to business functioning, efficiency and entrepreneurship, since they are considered ideologically contaminated and leading to thinking within the strict framework of capitalist rationality. The author does not agree with this view and considers it a "refractory attitude", as it is not possible to think of a society in which there are no relationships of exchange and economic activity. This author also advocates the need to rescue the term "entrepreneurship" within SSE, in addition to understanding the complexity of the entrepreneurial process and its adequacy to the needs of "associative entrepreneurship", typical of SEEs, in which the necessary ingredients are: cooperation at work, collective decisions, information exchange and a collective project.

In this sense, this article aims to discuss the state of the art of building the entrepreneurial ecosystem for SSE. Therefore, the article is organized in the following way: after the Introduction, we will discuss, in topic 1, some aspects of the entrepreneurial process, to later present the idea of the "triple helix" (topic 2). Next, topic 3 will address the entrepreneurial ecosystem construct for SSE in some countries, ending with some considerations on the Brazilian case. 


\section{Entrepreneurial process and ecosystem}

An entrepreneurial ecosystem is a community within a region of interdependent actors that interact with diverse roles, determining the performance of the ecosystem and eventually the entire economy of a region (Spilling, 1996). As a result of ecosystem performance, it is expected that, in addition to the results obtained by companies and other participant organizations (in terms of performance and learning), interaction will lead to the generation of new enterprises. Entrepreneurial ecosystems can have a favorable impact on the region's macroeconomics, and if their co-evolution is sustained over time, they attract new players that invigorate ecosystem performance (for example, companies or funds that may contribute to the appearance of a greater number of nascent enterprises). The elements that are part of an entrepreneurial ecosystem are by nature institutional, relational, and inserted within a natural and social environment. Cohen (2006) distinguishes the elements of the formal network from those of the informal network, which are:

A. Informal network: represents friends, colleagues and relatives of the entrepreneurs and their possible relationships with other companies in similar conditions to those that they are creating or directing.

B. Formal network: consisting of a variety of actors, such as research universities, local, regional or national government support services, business support services (consultants, accountants, lawyers), capital providers (banks, angel investors - seed capital), risk investors, large and medium-sized formal enterprises.

Next, some components of the formal network will be described, as adapted to the Brazilian case.

University of research: its importance is due to its potential for creation of new technologies, and promoting the combination of knowledge from several areas. According to the Carnegie Foundation for Advancement of Teaching, universities are conducting extensive research. The institution considers that an indicator of this are its fifteen PhD programs and the training of at least 50 doctors per year. On the role of universities, Kantis (2017), when reporting on the emergence of the Silicon Valley, states that a "very relevant ingredient" for the emergence of this ecosystem was the existence of a university such as Stanford, besides the existence of an entrepreneur (in this case, Professor Lewis Terman, with experience at the Massachusetts Institute of Technology - MIT). In Brazil, 23 universities meet these requirements (Lemos, 2011). Some of these universities have their own projects of technological parks. 
Government: they can create a favorable environment for entrepreneurs, reduce taxes and bureaucracy and create programs that favor the emergence and operation of these companies. When describing the emergence of ecosystems in the United States and Israel, Kantis (2017) argues that government plays an important role in the process of emergence of an ecosystem, taking into account the provision of financial resources for technological research and innovation, as well as in contributing with the basic infrastructure that provides better conditions of competitiveness to the territories. In the Brazilian case, there are governmental agencies, which have programs to support entrepreneurs, through granting of scholarships, capita contributions and the promotion of venture capital. Some are the National Study and Project Funding Agency (FINEP), the National Council for Research and Scientific and Technological Development (CNPq), the Foundation for Research Support of the State of São Paulo (FAPESP), National Bank of Development (BNDES) etc. The federal government (also some state universities, such as Universidade de São Paulo) have projects for the development of technology parks. Also through laws, such as the Supersimples Act (2007) - a system that facilitates the payment of taxes (a single monthly payment) at reduced rates; the General Law for Micro and Small Businesses (2006) - which facilitates accounting, access to credit and participation in government procurement.

Network and Support Services: consists of a set of actors that offer professional services to support the companies that provide inputs. In Brazil, the Brazilian Service for Support to Micro and Small Enterprises (SEBRAE) is the institution that offers the widest range of support services to small and medium-sized traditional entrepreneurs.

Sources of capital: sources of resources for nascent companies, whether in the form of venture capital or seed capital. In Brazil, credit lines are narrow and access is competitive for incubators or start-up companies.

Human talents: the nascent companies originate in talented people who, in addition, need qualified people to work in their companies. For this reason, technology-based companies and incubators emerge in places where there are universities that have related resources, which enable them to capture human resources and generate the ideas and people with the capacity to think about the business project that may be the origin of a new company.

Established companies: already established companies can play a role in the formation of entrepreneurial skills, based on the training and experience that people gain within them and which, later on, originate the spin-offs. The incorporated companies can be important clients of the nascent companies. The nascent companies tend to be located in regions where there are universities, given the greater offer of qualified people. 
Incubators: Business incubators are very important as an element of support to the nascent enterprises and may have their headquarters within a university, whether it is a research institution or not, or within facilities provided by a municipality or by some state or federal government program. Kantis (2017) - when addressing the emergence of the entrepreneurial ecosystem in Israel - mentions the interesting example of the "Incubators 2.0" program. This program is an experience that relates public and private funds, being operated by the government, which organizes a contest and selects institutional proposals submitted by local companies, as well as stimulates the emergence of foreign funds from large companies that are interested in investing in this type of incubation venture, while the "successful" incubated companies pay this investment through royalties, which vary between 3 and $5 \%$ of sales, until they finish refunding the grant. In Brazil, there are incubator networks per state that are organized within a national network. In addition to the physical infrastructure, they offer administrative and consulting services. SEBRAE provides financial support and advice to incubators and incubated companies. The National Association of Entities Promoting Innovative Enterprises (ANPROTEC) represents the interests of incubators, technology parks and innovative companies in Brazil.

Both the entrepreneurial process and its ecosystem have been considered fragile and needy of improvement in Brazil. An indicator that is constantly monitored is the survival rate of companies after two years of existence, which is $76.6 \%$ (SEBRAE, 2016). This indicator has improved significantly over the last few years, due to several factors, among which is SEBRAE's action and the improvement of the regulatory environment (Supersimples Act, Individual Microentrepreneur Law).

Based on the concepts of process and entrepreneurial ecosystem for businesses of mainstream economy, it is necessary to reflect on the entrepreneurial ecosystem for the Solidarity Economy enterprises (SEEs), considering the characteristics of the participants in this segment.

An interesting contribution in the systematization of the structure of this process can be seen in studies conducted by the European Community (2016) and, in the Asian perspective, for the South Korean case (Kim, Jung, 2016), which will be presented in detail later.

From these studies, a coherent structure of organization of the ecosystemic process of solidarity entrepreneurship implies the following components: a) Knowledge; (b) Market access; c) Public and fiscal support for start-ups of SSE; d) Access to financial support; e) Instruments to support networks and mutual support and f) Development of research and qualification in the area.

It is important to include the capacity to create EES evaluation and monitoring indicators in this structure; a difficult and complex task, but extremely relevant, being one of the greatest challenges in the 21 st century.

This, therefore, adds to the above-mentioned components, the fact that the concept of "ecosystem" itself is a systemic concept, encompassing, as Serrano (2015) suggests, aspects of "complexity 
theory" (Edgar Morin) and "theory of systems" (referring to the "complex adaptive system theory", which describes the emergence, adaptation, and self-organization of these systems).

In this perspective, one of the ways to face such a challenge regarding the structuring of these components is to combine efforts and responsibilities of joint construction among the SEEs, the university and public policies (this, necessarily within the process of co-construction among the agents). This statement needs deeper discussion, from the perspective of the idea of "triple helix".

\subsection{Brief considerations on the composition of the solidarity entrepreneurial ecosystem from the view of the "triple helix"}

In dealing with the importance of entrepreneurship, university and public policy in the composition of the entrepreneurial solidarity ecosystem, we come to the idea of the relevance of achieving the "synergistic potential" to articulate and integrate the "triple helix" in favor of the entrepreneurial solidarity ecosystem.

As Lemos points out (2011: 44):

"For the ecosystem treatment to be a viable approach to strategic planning and management of entrepreneurship, it is important to present the reasons that make the triple helix a predominant view and practice."

In his study, we can see some reasons, among them are: i) the triple helix approach combines economics with a strong sociological perspective of innovation systems, which would be a distinctive feature of this perspective; ii) triple helix approach is aimed for application in public policies and its management in research institutions, universities and international organizations; (iii) this approach functions as a facilitator of planning, management and implementation, decision-making processes and policy assessments.

In the triple helix approach, three "critical assets" are considered relevant for the development of the entrepreneurial ecosystem: a) assets focused on innovative activities; $b$ ) assets for entrepreneurial actions and c) bridge assets, which should be formed by people and mechanisms responsible for the induction and coordination of the interaction between entrepreneurs and knowledge.

Moreover, this approach: a) is focused on a "bottom-up model", since systems must be thought so as to lead to the valorization of people and related groups; $b$ ) understands how important the ability of orchestration and articulation is (of crosscutting nature), as a way of characterizing the theoretical guidelines of this methodology; $c$ ) it relies on the ecological vision of systems and networks, 
not by means of "natural selection", but through the considerations on interactions (ecological and evolutionary) that integrate the entire ecosystem, all species and all organisms of a given habitat and their physical environment.

Such premises allow for the idea of "co-evolution" to emerge when organizations can interact with their ecosystems and ecosystems interact with organizations. Still, according to Lemos (2011), it is necessary to point out that co-evolution is a cross-cutting concept, which is capable of acting both at the micro level and at the macro level, and which is a key element in the development of the ecosystem perspective. In other words, it is necessary to consider which organizations can co-evolve in broader instances, such as co-evolution in relation to technological trajectories, social, regulatory and institutional environment. That is, it is a joint development with the environment, in which they are inserted and integrated.

In addition, what will keep the ecosystem's leadership going will depend on the ability of the organization(s) to convince the components of the ecosystem that it is worthwhile to continue to evolve together, that is, evolving. In other words, the collective (and not individual) vitality of the ecosystem is a condition of its own sustainability, maintenance, and evolution. Rather than focusing only on their internal skills, resources and internal capabilities, stakeholders should know the interdependencies among ecosystem organisms and emphasize the collective properties of the business networks and ecosystems in which they participate (lansiti and Levien, 2004).

Another fundamental element of the ecosystem construction is the degree of interconnectivity, that is, of interdependence that all the components of the system keep among themselves. For Lemos (2011: 59):

"This interdependence is similar to a food chain - it ensures the productivity, creativity and stability of the ecosystem. That is why some species are beneficiaries of the inputs of others and are able to concentrate on their activities without having to produce the inputs that they use and are dependent on. The key species are true platforms for other species. Its decrease or disappearance causes deep imbalances or even the disappearance of the ecosystem. These are the defining species that give the tone of the ecosystem's health."

In this sense, we understand that the SSEs provide fertile ground for the need to build a process that must be permeated by a bottom-up and crosscutting perspective, enabling co-evolution towards "collective vitality", with degrees of interconnections. Although with structural weaknesses, SEEs imbued with elements of SSE allows for the emergence and strengthening, in their modus operandi, of these characteristics suggested for the construction of entrepreneurial solidarity ecosystems. 


\section{The entrepreneurial ecosystem construct for SSE}

According to what has been stated, we can say that the construction of the entrepreneurial ecosystem is a complex task and marked by numerous challenges. As already mentioned, these challenges derive from the recognition of this concept as something systemic and dynamic. When specifically addressing the entrepreneurial ecosystem for the SSE, such complexity and challenges intensify, given the inherent structural weaknesses that characterize the SSE, as well as the still open field of institutionalization of its policies (Morais \& Bacic, 2016).

In general, as systematized by Serrano (2015: 173), ecosystems are "network of actors" (entrepreneurs, researchers, funding institutions, politicians - executives and legislators, etc.) that take into account the physical-territorial dimensions and the territory concerned. This territory is marked by a set of systems, such as: a) political systems (alliances and coalitions between social actors and political actors that form the basis for territorial governance); (b) production systems (which lead to networks of actors involved in the production of goods and services); and (c) territorial innovation systems (created by some stakeholder groups involved in the generation and diffusion of innovation). These systems determine a context leading to sociological, political and economic consequences. Still, for this author, the ecosystem construct must also take into account the need to promote "selfreflection", that is, to be able to analyze itself in an "endogamic" way, based on the research, the creation of statistics and impact analysis, as well as the need to open up and strengthen ties with social movements.

In practical terms, there are already examples in some places in the world that can help and inspire us. Next, some information about the European and Asian cases will be presented. These are regions where there is some progress already in achieving and registering the entrepreneurial ecosystem for SSE.

\section{a. The European case}

In this region, it is possible to verify the importance given to the theme related to the ecosystem for the SSE, with particular attention to social enterprises. An important ecosystem mapping study is currently under way for these companies in 21 Member States of the European Union and seven European non-member countries procured by the European Commission (2019) from the European Research Institute for Cooperative and Social Enterprises (EURICSE) and the EMES International Research Network (EMES). This study describes the main characteristics of social enterprises, 
providing an overview of the ecosystems of social enterprises among countries, including factors that constrain their development. For those responsible for the study, the number of social enterprises in Europe is increasing and they are engaging in economic, social, political, cultural and environmental fields. In addition, many countries are introducing new legislation as well as new schemes of financial support to boost the development of these companies. However, there are also constraints and challenges that can hinder the expansion of these organizations. That is why we need to increase our knowledge on the topic.

In recognizing the complexity inherent in the process of building the ecosystem for social enterprises, the study "Social enterprises and their eco-systems: developments in Europe" suggests the existence of two fundamental pillars: public support policies and self-organizing capacity of civil society.

This study - based on the elements described above - public support policies and the selforganizing capacity of civil society - in a disaggregated way, proposes a structure to approach the ecosystem that includes: a) knowledge - political awareness and legal forms of recognition of these policies and action; b) access to markets; c) public and fiscal support for start-ups of SEEs; d) access to financial support; e) tools to support networks and mutual support; f) development of research and qualification in the area. According to the European Commission study (2016: 19):

"National reports confirm that, rather than depending upon one factor alone, the ecosystem is shaped by the interplay between all these factors".

A more detailed analysis of the building structure of the entrepreneurial solidarity ecosystem (or for social enterprises, in the specific case of the European Union) brings us some interesting information.

In terms of the first element (knowledge - political awareness and legal forms of recognition of these policies), depending on the country, this recognition comes from different instruments, such as: specific laws for social enterprises (United Kingdom case) or for the SSE (cases of Spain and Italy); creation of ministries, secretariats or departments relevant to the theme (cases of Bulgaria with the National Social Economy Concept or of Poland with the National Program for Social Economy Development); elaboration of official documents highlighting the role of SSE strengthening programs.

Regarding market access, the second element of the constructive structure of the European social ecosystem, social enterprises and/or SSE have products and services that can be directed to the demand of the public and private sectors. Therefore, there are public policies or programs to strengthen these enterprises, especially on three fronts, depending on the country: promotion, integration or replacement (of services previously offered by the State and which are now offered by social enterprises, such as, for example, support services for the elderly, children, community 
development services, etc.). An important factor for the strengthening of these measures was the creation of the EU Public Procurement Rules, of 2014. This regulation aims to offer new opportunities and incentives for the creation of social enterprises, especially those focused on the provision of social and health services. It is worth mentioning that, as of May 21, 2016, member States were willing to initiate and adapt to this important regulation at European level. As examples, countries such as France, Ireland, Italy, Poland and Slovakia have introduced aspects of this Regulation in their respective national legislations between 2015 and 2016. In this perspective, it is also worth mentioning the legal recognition of "market reserve" policies for some social enterprises, as in Italy and Slovakia, which guarantee the insertion of physically and mentally disabled workers.

The third element of the structure deals with public and fiscal support for SSE start- ups. In all the countries analyzed, we can observe that the fiscal structure inserted in the SSE field is complex, heterogeneous and fragmented. This fact is also due to the heterogeneity of organizations that make up the SSE (cooperatives, associations, foundations, social enterprises, etc.). In general, tax arrangements for such organizations are classified into three types: (a) reduced social security contributions; (b) tax exemptions and lower rates; and (c) tax reductions for private or institutional donors. In Belgium, for example, there is a reduction in the social contribution of organizations that work with social and health services, while in France, associations working with cultural and sporting activities are exempt from value-added tax on their activities (Value Added Tax - VAT). In Ireland, charities, which may include some social enterprises, pay less tax. In Italy, social cooperatives are exempt from the corporate tax (IRES), in addition to having special treatment in relation to VAT.

Regarding support for SSE start-ups, measures differ among governments (central and regional) and according to the type of enterprise. In some countries such as Belgium, France, Italy, Poland and Spain, the importance of close cooperation with local authorities for the development of SSE is recognized. To give an idea, in France, the Rhône-Alpes Region is a clear example of a region that systematically promotes SSE. In Ireland, the origin of public support for the SSE came, since year 2000, from the Social Economy Program and the Community Services Program.

Access to financial support is the fourth element in the European ecosystem's construct structure for SSE and it is considered a strategic issue. In view of the previously mentioned heterogeneity of the organizations that make up the SSE, each organization presents its facilities and difficulties with regard to the financial support theme. Some of them hold more self-financing abilities, in view of the significant donation scale of their volunteers. Other organizations rely heavily on public credit or specific banks (for example, cooperatives, rural areas, housing, etc.) to carry out their activities.

In general: i) financial instruments that aim social innovations are more recent and receive increasing attention and importance. Examples are: impact investing; social impact bonds; social venture capital; crowdfunding etc.; (ii) the main difficulties in having access to funding discussed in the country studies are the absence of a "strong investor" as well as the lack of ability to develop adequate 
projects and, consequently, to be financed more easily. In this sense, the study of the European Union draws attention to the fact that "there is a need for adequate policies that are able to encourage social enterprise capitalization by means of innovative financing tools" (p.36).

Networks and mechanisms of mutual support are another fundamental element in the structure of the European ecosystem for SSE. Where these exist, the chances of success of the SSE are much higher than when there is no establishment of networks and mechanisms of mutual support among the enterprises. In addition, networks allow replicating positive experiences in economic, social and political terms. In analyzing the European countries, the study states that networks (p. 37): "have played an important role in legitimizing the emergence of a new type of cooperative, with an explicit social aim, and have successfully lobbied for the introduction of enabling policies by participating in the drafting of new legislation and policies". The same occurred in France (Les Scop, network of SCOPs), Italy (Confcooperative and Forum del Terzo Settore) and Spain (CEPES).

Last but not least, the themes concerning education and capacity building, skills and knowledge development appear in the structure of the European ecosystem for SSE. According to the study, this subject area represents "a new field of scientific inquiry", "although it is attracting the interest of a growing number of researchers, research in this area is still fragmented, often mono-method and mainly descriptive and classificatory" (p.39). This recognition also stems from the fact that the SSE is not regulated by a single legislation, but by several laws (when they exist), which vary by type of organization and/or country of operation.

However, it should be stressed that "the number of educational and training programs tailored for social enterprises is also growing significantly". In France, for example, SSE-linked study modules are integrated into university-level programs, accounting for more than 70 SSE courses in the country in 2012, according to data provided by the European study. In this country, there is also an interuniversity network (RIUESS) of professors and researchers specialized in SSE. Besides, in Belgium and Italy, several universities have included in their courses subjects in the field of SSE and related subjects. In terms of skills and knowledge development, the European study shows that:

"In all the countries studied, including those where social enterprises have grown in number and size and have proven to be efficient providers of a wide set of general interest services, management has remained an area of weakness. This is mainly due to the fact that many social enterprises developed from community groups. Consequently, they are still staffed, to a significant extent, by volunteers, or they may not have the ability to recruit staff to meet specific managerial skills" (p. 40).

The relevance of developing training and research centers for SSE in particular is justified by the fact that "mainstream business support has not been effective in engaging with social enterprises, instead prioritizing more traditional commercial businesses." As the Document states, just reproducing 
practices used in traditional ventures "disregards the potential of social enterprises to develop alternative models that are more efficient and consistent with their peculiar local roots, including dimension and explicit social aims" (p. 40). In addition, this will help SSE to develop its potential and specifically consolidate its potential as "a true alternative to current unsustainable mainstream economic practices".

Regarding the process of constructing indicators for evaluation and monitoring, the recent one conducted by Monzon \& Chaves (2017), carried out for 28 European countries, brings us a significant leap forward regarding the quantitative information of the SSE, up to the year of 2015. This information refers to the number of people employed in cooperatives, associations, mutual societies etc., as well as a relation between the total occupation in SSE organizations and the total occupation in Europe. From this information, it is interesting to observe that there is a divergence among the 28 countries, since this ratio is in average $1 \%$, in countries such as Lithuania $(0.6 \%)$, Croatia and Slovenia (1\%), Malta $(1,3 \%)$ and Romania $(1.7 \%)$, reaching around $10 \%$ in countries such as Luxembourg, the Netherlands, France and Belgium. This study also brings the number of associates and organizations, by type, among the 28 countries.

In addition to these data, an even greater leap was given, albeit in a panoramic and incipient way - which also reveals the embryonic stage of the topic at the international level - in Chapter 8, entitled "Methods and indicators to evaluate the social economy and its impacts." According to the study:

"There is a growing interest in statistics about the social economy. However, given that the social economy is a relatively new concept in the field of national statistics, it faces many challenges. Among these are the identification of the statistical population as well as the use of appropriate methodologies and indicators. That said, the current production of social economy statistics does succeed in conveying certain aspects of the output of the social economy (...) Statistics on the social economy are needed in order to quantify the relative weight of this type of economy, counteract its lack of visibility and improve overall knowledge and recognition of the field. Quantification and evaluation are crucial steps for gaining a better understanding of the social economy and its place and role. Statistics also have a pragmatic function in that they allow development and assessment of public policy concerning the social economy at different territorial, national and international levels" (Monzon \& Chaves, 2017: 92).

Still according to this study, the first task in any production of statistics is to define the "object" or "beings" to be measured. In the case of SSE, it is necessary to identify the "entities" that are part of this "sector", as well as to verify the existence (or not) of a legal framework and, if such activities are or not included in the National Accounts of the respective countries. Since this "sector" is permeated by conceptual and theoretical vagueness, that is, by the absence of consensus in its definitions, a set of five criteria can be used to distinguish "entities" that belong or not to the field of SSE. These are: (i) social mission (a principle that overrules all other criteria); (ii) the limited or forbidden distribution of 
surpluses, expressed mainly in the legal identity of an organization (cooperative, mutuals, association, foundation), or by the presence of such a restriction in the bylaws; (iii) the presence of employees and/or volunteers; (iv) the decision-making process of the organization and (v) the existence or not of "democratic governance" (involving the right of stakeholders such as users, workers, members, etc.) to oversee decisions within the organization.

Further, screening methods can be applied in various (non-exclusive) ways, namely: selection based on administrative data; selection based on records kept by the government. The first two methods, in the European case, related to the elaboration of SSE Satellite Accounts; validation of data prepared and updated by SSE networks (or creation of SSE Observatories), as well as the use of specific questionnaires. However, the choice will depend on the degree of institutionalization of the "sector" in each country and the consequent advances in the elaboration of quantitative materials about the "sector".

In general terms, on this very important issue of quantification of SSE, we observe that, presently, one of the issues in producing statistics for this "sector" is that the operational definition varies according to the country and very few countries have records on their statistical accounts. However, in recent years, we acknowledge a considerable work that has been undertaken, in order to map the SSE, which, however, has resulted in the production of a variety of notions and types of SSE, with several methodologies for calculating the weight of SSE in GDP, in total employment, etc. This reflects the economic, political and ideological diversity of SSE, beyond the complex and arduous difficulty of conceptualizing and defining the "sector". Undoubtedly, this is one of the most relevant themes for SSE in this 21 st century; which should be addressed in a specific article.

\section{b. The case of Asia}

In the case of the construction of the entrepreneurial ecosystem in Asia, we will look at the example of South Korea, with the Local Economic Ecosystem Development Project (LSEEDP). It was created to guarantee the sustainability of the South Korean SSE. According to KIM and JUNG (2016: 40):

"The goals are to strengthen internal cooperation and networking among actors of the local social economy, and thereby to induce a healthy and thriving social economy ecosystem based on their cooperation. Local strategic projects are intended to ensure the embedding of the social economy in local communities".

In the South Korean case, the structure that has been developed includes local governments (with their respective support policies), SSE networks (and their cooperation centers) and civil society (consulted in their participatory forums). In this ecosystem, "asset formation" (in terms of infrastructure, human resources and market expansion) is a fundamental element and the entire process leads to 
"local strategic projects", where projects are designed to support the incubation of SSE enterprises and local development. Although integrated, LSEEDP prioritizes local development projects from ecosystem groups that are specific for each borough, which are supported for a maximum of five years, until they reach levels of autonomy. This process is divided into two stages, the first of which is to promote the capacities of civil society (read the selected "neighborhoods") and the second to assist economic, financial and legal issues of the potential ventures initiated.

Another interesting aspect concerns the creation of the "Social Economy Zone" (SEZ) in order to "allow each borough to identify and make strategic use of local resources available for sharing, in order to solve local problems through local cooperation "(page 49). Examples of areas already created include the Social Fashion Ecosystem Development Project in the Seongdong region and the Local Social Service Center in Seongbuk, as well as areas linked to the development of new social entrepreneurship models in tourism, art and culture, such as those developed in Mapo and those of recycling activities in Nowon.

It is important to understand that the idea and actions aimed at strengthening the entrepreneurial solidarity ecosystem in Seoul are part of Seoul's Social Economy Policy (2011-2015), with the clear and explicit objective of fostering an ecosystem for greater self-sufficiency. The program allocated KRW 50 billion (equivalent to about USD 45 million in 2017 amounts) for the Seoul Social Investment Fund to carry out its projects.

\section{The entrepreneurial ecosystem for SSE in Brazilk advances, setbacks and challenges}

Before dealing specifically with the Brazilian case, there are some more general considerations about Latin America. In this region, a recent study on cooperativism and SSE (Bajo, 2017) shows an increasing importance of public policies in strengthening the sector, with attention to its connections to local development, social inclusion and resilience practices in territories considered vulnerable, in social, economic and political terms. An example is the case of Colombia, during its pacification process, which also included the generation of opportunities via SSE. The studies also point to the importance of strengthening civil society, not only in economic terms, but also in terms of building capacities for social cohesion and democratic governance. In microeconomic terms, the country studies have demonstrated an increase in the relevance of financial sustainability issues in the SSE, as well as practices of cooperation and networking between cooperatives and SSE in general; practices that are being systematized more frequently and with a rigorous eye on methodology. As an interesting example, we mention the case of Ecuador and the innovations based on the experience of "organic networks". These experiences also occur in Cuba, Costa Rica, Paraguay, and so on. (Bajo, 2017). 
Taking into account the discussion about the construct of entrepreneurial solidarity ecosystem, when we consider the community participatory processes as its genesis, we should point that this study draws attention to the fact that a few experiences are succesful in the second stage, along the constitution of cooperatives in the region. According Bajo (2017: 7):

"cooperatives appear after communities begin taking part, to some degree, in the process of building their own citizenship, their own inclusion into a process of co-construction of norms and practices, raising the question of whether cooperatives are a result of increased consciousness regarding common needs as well as newly discovered capacities - in this sense carried on the shoulders of social movements".

Still referring to the elements of the ecosystem for Latin America, we should mention that, according to Vuotto (2017), the importance of measuring and evaluating and monitoring the activities of SSE is also addressed in more recent studies. In the author's view (p. 22): "other ways of approaching knowledge that can be found in studies include systematization and evaluation (...) evaluation produces information for decision-making as a means to optimize project management".

In Brazil, the term SSE does not find consensus, although the organizations that act in the interface between the economy and the society constitute an expressive and increasingly acknowledged social phenomenon. As far as the praxis sphere is concerned, one can see a wide range of actors and legal forms that constitute this field, while the cooperatives are the easiest to distinguish and the ones with longer tradition in our country.

In the specific case of the "Solidarity Economy" (SSE), in the country, a landmark for the beginning of the institutionalization could be the emergence of the National Secretariat for Solidarity Economy (SENAES) in 2003, although its origin comes from social movements, as well as real experiences, prior to its creation.

Since 2003, until now (2020), the Secretariat, as part of the "Solidarity Economy in Development Program", has gradually entered into the Pluriannual Plans of the Federal Government (2004-2007, 2008-2011, 2012-2015), constituting the beginning of the process of institutionalization of SSE as public policy in Brazil. In other words, the beginning of a legal framework for the Solidarity Economy under construction. There were also strategies for the expansion of state and municipal public policies for Solidarity Economy, as well as the emergence of the Public Solidarity Economy Centers and the Parliamentary Front of the Solidarity Economy. Also important was the emergence and strengthening of both the National Solidarity Economy Conferences and the National Solidarity Economy Council. From the economic point of view, the "sector" represents about $8 \%$ of the national Gross Domestic Product (GDP) and two million jobs. 
Regarding numbers for the SSE, the last national mapping of SSE was carried out and published in "The Solidarity Economy in Brazil: an analysis of national data", under the coordination of Gaiger (2014). This mapping can serve as a characterization of SSE in Brazil after thirteen years of public policies carried out by SENAES. Based on this mapping, there are 19,708 SEEs and 1,423,631 associates. Of these, almost 55\% are in the rural area, while 34.8\% are in the urban area and $10.4 \%$ of the SEEs operate simultaneously in rural and urban areas. In Brazil, $41 \%$ of the SEEs are in the Northeast, $17 \%$ in the South, $16 \%$ in the North, the same figure in the Southeast and $10 \%$ in the Center-West. As for the organization of SEEs, there is a large predominance of associations, taking $60 \%$ of SEEs, $30.5 \%$ are informal groups, $9 \%$ are cooperatives and less than $1 \%$ are commercial businesses.

However, in spite of the potential and advances for SSE in Brazil, this "sector" is affected by certain fragilities, as previously mentioned. These weaknesses are, according to Morais \& Bacic (2016), in:

a. Micro-economic fragilities: market conditions (supply and demand of products and services), pricing and production costs, marketing conditions, access to technology, access to working capital of enterprises, etc.;

b. Macroeconomic weaknesses: more general conditions for the functioning of the economy and the exclusion of certain groups of access to credit under facilitated conditions; high interest rate; impacts of the fiscal tightening on the continuity of programs, projects and actions etc.;

c. Support of public policies: the absence of integrated and crosscutting actions (among ministries, secretariats, etc., at the federal, state and municipal levels) that slow down the potential advances towards the goals of generating jobs, employment and income and of spreading experimentation with diverse solutions. This is also due to the vagueness regarding the definition and measurement of this "sector".

In a recent study, Gaiger \& Kuyven (2019), from a close look at the mapping os SSE (2014) mentioned above, point out that the main challenges of SSEs are, fundamentally, in order of importance: i) economic, adequate income for partners and economic viability of SSES and ii) social and political, internal and external, linked to the maintenance of the union of groups and or collectives, in order to make self-management effective and to promote the articulation with other SSEs. In this sense, the authors reveal that the issues of adequate income and economic viability are pointed out mainly by the SSEs of work and income generation, with a slightly greater emphasis when they face difficulties to remunerate the partners or when they provide income supplementation. In turn, SSES for the consumption of goods and services and community development highlight the challenge of reaching partners' awareness and politicization, in addition to greater environmental awareness.

Thus, we can state that the existence and strengthening of the entrepreneurial solidarity ecosystem are important allies in facing these fragilities intrinsic to SSE. 
In August 2017, an important step was taken towards the institutionalization of SSE's public policies in the country, with the approval, by the Chamber's Constitution and Justice Commission (CCJ), of Law Project 4685/12, which creates the National System of Solidarity Economy. However, the ecosystem's structure goes beyond the legal framework, which in itself is extremely relevant.

In this perspective, even in times of economic and fiscal crisis, associated to the changes that resulted in the extinction of SENAES (along Temer's Government, with even worse perspectives in Bolsonaro's Government - as will be discussed below), the construction of the entrepreneurial ecosystem - yet without a clearly defined structure - can be seen through some actions, projects, and programs.

The following table is based on the components previously described, which suggest a framework for the construct of the European ecosystem for SSE. This exercise allowed us to see that in Brazil there are seeds of this structure, although not formalized.

\section{Table 1. State of the art of the entrepreneurial ecosystem for SSE in Brazil}

a) Knowledge - political awareness and legal forms of acknowledgement of these policies and action: SENAES

b) Market access: Food Acquisition Program (PAA); National School Feeding Program (PNAE); Solidarity Economy Markets

c) Public and fiscal support for start-ups of SSE: SENAES (Ex. Networks Project)

d) Access to financial support: National Study and Project Funding Agency (FINEP); microcredit, solidarity revolving funds, community banks (e.g. Palmas Bank, Cocais, etc.)

e) Instruments to support networks and mutual support: Brazilian Forum of Solidarity Economy (FBES); National Council for Solidarity Economy (CONAES); Project Networks, etc.

f) Development of research and capacity building in the area: Technological Incubators of Popular Cooperatives (ITCPS), Network of public incubators of joint ventures of UNITRABALHO; Study Centers - Analysis of formal and informal SSE

SOURCE: Own elaboration based on European Comission (2016).

In general, Table 1 shows that, from the point of view of public policy and the participation of civil society, the Brazilian Solidarity Economy Forum (FBES), the creation of SENAES in 2003 and its various projects and actions are important. 
Other "seeds" of the ecosystem in the country are:

a) universities that, even in difficult times, are financially supported by the federal government (by means of public notices or projects) to act as incubators of SSE enterprises through ITCPS - Technological Incubators of Popular Cooperatives. There are also some municipal and state governments that present projects and actions in the area. Besides, there is the Network of the public incubators of joint ventures of UNITRABALHO;

b) banks that work with microcredit and/or with social currencies. These community banks are a reality in some municipalities in the country, and account for a network of more than 100 community banks (such as Banco Palmas);

c) financial support of SENAES (although presently it is extremely restricted and even paralyzed) for specific projects such as the Networks Project (SEEs network development - completed in 2016 and waiting for renewal), projects for the recycling chain etc.;

d) demand guarantee programs (market access) such as the PAA and PNAE mentioned in the table, which are programs that give permission for public purchase - without bidding - of food from SSE, mainly from small rural producers;

e) existence of formal and informal SSE networks as well as important support institutions, discussion and political strengthening for SSE, such as the above-mentioned FBES and CONAES;

f) a broad and increasing base of studies on SSE in universities (courses in Economics, Social Sciences, etc.) in undergraduate and postgraduate courses, either in specific training courses in the area, or in undergraduate or graduate studies final essays or theses ( specialization, Master's and Ph.D degrees). This can be confirmed through an examination of the data mentioned in Icaza study (2017), which points to a significant growth of research in the areas of cooperativism and SSE in the last two decades;

g) developments in the elaboration of Municipal Councils of SSE and of Municipal Laws of SSE, as in the cases of the municipalities of Araraquara (SP), Balneário Camboriú (SC), etc.

However, the political and economic moment is of apprehension with respect to the strengthening of the entrepreneurial solidarity ecosystem in the country, in view of the recent cuts in financial support of SSE's public policies (SENAES), as well as related policies, since the change of government in the country (Government Temer - 2017 and 2018).

This apprehension was intensified in 2019, with the extinction of what had already been turned into a Sub-secretariat of SSE, through the Provisory Act 870/2019. It is important to recall that during Michel Temer's government, SENAES maintained its dynamics within the Ministry of Labor, but became a sub-secretariat of SSE, instead of secretariat, with a drastic reduction of its budget, which restricted the support and promotion policies. In order to give an idea of this, Silva (2018) coined the term "paradigm crisis" to refer to what happened between 2016 and 2018, when analyzing SSE's public policy in Brazil, in the budget cycle from 2004 to 2018. Taking 2015 as the year of reference, according to the author, in 2016, SENAES's budget was 50\% compared to 2015 ; in $2017,60 \%$ of the value and, in 2018 , only $16 \%$ of the value of 2015 . 
In 2019, as mentioned before, this tendency was consolidated through the publication of Provisory Act 870/2019, in which the new government reorganized the Ministries and their institutional structure. Initially in the Ministry of Labor, SSE is now subordinated to the Ministry of Citizenship. In addition, when analyzing Decree No. 9,674, dated January 2, 2019, which details the structures and positions of the Ministry of Citizenship, we can observe, unfortunately, the extinction of SENAES. Thus, the late SENAES, which had been gradually expanding actions and policies to support and promote SSE in the country, became a Department of Solidarity Economy, within the National Secretariat for Social Inclusion and Urban Productivity. This seems to indicate that the current government tends to think of SSE under a philanthropic perspective and not as an alternative for generation of jobs and income.

In other words, it is sad but, in addition to cuts in budget and in the status of the Secretariat, these changes also have an impact on the meaning of SSE in the current government. The present government seems to be moving towards a more charitable and philanthropic vision, with a taste of individualistic entrepreneurship; a vision that is far from a more cross-sectional, emancipatory and questioning attitude in the development and income generation strategy, fragmenting the policies and actions of a movement that organizes itself in a self-management and collective way.

In addition, it is important to mention that we still need a legal context for SSE, with clear and relevant legislation. Beyond this, it is necessary to improve the agents' performance in order to recognize the limitations and specificities of the SEEs and design coherent policies and actions to overcome them, as well as to advance in the creation of evaluation and monitoring indicators of the SEEs.

\section{Final conclusions}

The formation of the entrepreneurial ecosystem for the SSE is a fundamental tool for the emancipation and strengthening of the SEEs, in view of the structural weaknesses inherent to its modus operandi. As we tried to demonstrate, the following components should be part of a coherent structure of organization of the solidarity entrepreneurial ecosystemic process: a) Knowledge; (b) Market access; c) Public and fiscal support for start-ups of SSE; d) Access to financial support; e) Instruments to support networks and mutual support and f) Development of research and skills in the area. We emphasize that it is important to include the capacity to create evaluation and monitoring indicators for SEEs in this structure. This is a difficult and complex task, but one that is extremely relevant and also one of the greatest challenges in the 21 st century. 
Besides this composition of ecosystem structure, it is important to call attention to the fundamental role of the following actors, as well as their efforts and responsibilities of joint construction: the SEEs, the university and participation in the co-construction of public policies. Additionally, we believe that the maintenance of ecosystem leadership will depend on the ability of its actors to convince themselves that it is worthwhile to continue evolving together, that is, to co-evolve. In other words, the collective (and not individual) vitality of the ecosystem is a condition of its own sustainability, maintenance, and evolution. Instead of focusing solely on their internal skills, resources and capabilities, stakeholders should be aware of the interdependencies among ecosystem organisms and emphasize the collective properties of networks of SEEs. Therefore, another fundamental element of ecosystem construction is the degree of interconnectivity; of interdependence that all the components of the system hold together, as well as the need to build a process that must be permeated by a bottom-up and crosscutting perspective, enabling co-evolution towards a "collective vitality" and with degrees of interconnectivity.

In practical terms, there are examples in some parts of the world that can help and inspire us, such as some European, Asian and Latin American cases.

Regarding the Brazilian case, in spite of the potentialities and advances in SSE in Brazil, this "sector" is marked by certain weaknesses, as previously mentioned. These weaknesses are fundamentally related to: a) Microeconomic fragilities; market conditions (supply and demand of products and services), pricing and production costs, marketing conditions, access to technology, working capital of enterprises etc.; b) Macroeconomic weaknesses: general conditions for the functioning of the economy and the exclusion of certain groups of access to credit under facilitated conditions; high interest rate; impacts of fiscal tightening on the continuity of programs, projects, and actions; and c) Public support policies: the lack of integrated and cross-cutting actions (among ministries, secretariats, etc.) at the federal, state and municipal levels, which slow potential progress towards the objectives of generation of work, employment and income and the very existence of several experiences. This is also due to the absence of clear definitions and measurements of the "sector".

Thus, we emphasize that the existence and strengthening of the entrepreneurial solidarity ecosystem are important allies in facing these fragilities intrinsic to SSE.

In December 2019, the Senate Plenary approved the Project (137/2017), regarding the construction of the National Policy for Solidarity Economy and the National System for Solidarity Economy, however, without clarifying how and where the funds for financing this policy will come from. Also, this approval occurred in a context (2020) of public policies against SSE in Brazil.

Despite the progress towards the institutionalization of public policies for SSE in the country, with the approval of this Project, a process of deterioration of the SSE public policies could be observed in Brazil, considering the drastic and permanent cuts in resources for SENAES since 2015-6. However, as we can see, the worst was yet to come: the burial of SENAES, due to the extinction of what had 
already become just a sub-secretariat and its inclusion, as a board, in the newly created Ministry of Citizenship.

We hope that such a scenario will change, so as to increase the sensitivity to the importance of SSE in the country. It is necessary to understand SSE in a broader perspective, crosscutting, emancipatory and not as something charitable and philanthropic. SSE deals with the creation of jobs, employment and income and the resulting economic dynamism, but also includes - as its core - aspects of local and community development, as well as greater political participation, turning participant actors into elements of the co-construction of their goals and in facing their challenges.

\section{Bibliographic References}

ALBAGLI, S. \& MACIEL, M.L. (2004): "Informação e conhecimento na inovação e no desenvolvimento local”, Ci. Inf, Brasilia, 33 (3), 9-16. Available on lineat: http://www.brapci.inf.br/_repositorio/2010/02/ pdf_65f187e98d_0008132.pdf.

BACIC, M. (2014): "Da oportunidade de pensar no desenvolvimento de um ecossistema empreendedor para os empreendimentos de economia solidária em América Latina", 4ª Academia Internacional sobre Economia Social e Solidária da OIT - Campinas, 2014. ILO, Geneve.

BAJO, C. (2017): "Research on cooperatives in Latin America, an overview of the state of the art and contributions", Review of International Co-operation, International Co-operative Alliance, 104, 3-13.

BARQUERO, A. (2018): "Reflexiones teóricas sobre la relación entre desarrollo endógeno y economía social", Revista Iberoamericana de Economía Solidaria e Innovación Sociológica, 1, 11-22.

BRÄNNBACK, M., CARSRUD, A., KRUEGER Jr, N. \& ELFVING, J. (2008): "Challenging the triple helix model of regional innovation systems: A venture-centric model", International Journal of Technoentrepreneurship, 1 (3), 257-277.

COHEN, B. (2006): "Sustainable Valley Entrepreneurial Ecosystems", Business Strategy and the Environment, 15 (1), 1-14.

COMISSÃO EUROPEIA (2016): Social enterprises and their eco-systems: developments in Europe. Luxemburg, Available on line at: http://europa.eu/.

EUROPEAN COMMISSION (2019): Social enterprises and their eco-systems: developments in Europe, Luxemburg. Available on line at: https://ec.europa.eu/social/main. jsp?catld=738\&langld=en\&publd=7934\&furtherPubs=yes. 
GAIGER, L. (2008): "A dimensão empreendedora da economia solidária: Notas para um debate necessário", Outra Economia - V. II - № 3 - 2०.

GAIGER, L. (Org.) (2014): A Economia Solidária no Brasil: uma análise de dados nacionais, São Leopoldo, Rio Grande do Sul, Editora OIKOS.

GAIGER, L. \& KUYVEN, P. (2019): "Dimensões e tendências da economia solidária no Brasil", Sociedade \& Estado, 34 (3), DOI 10.1590/s0102-6992-201934030008.

GIL, A.C. (2008): Métodos e técnicas de pesquisa social, $6^{\mathrm{a}}$ ed. Editora Atlas.

ICAZA, A. (2017): "Status, advancements, and challenges for the research on cooperatives in Brazil". Review of International Co-operation, International Co-operative Alliance, 104, 25-32.

KANTIS, H. (2017): Surgimiento y desarrollo de ecosistemas: una mirada evolutiva sobre dos casos emblemáticos, Programa de Desarrollo Emprendedor (PRODEM). Brief $n^{\circ}$. 1, Parte A, September.

KIM, Y. \& JUNG, T. (2016): Status of Social Economy Development in Seoul: a Case Study of Seoul, GSEF Social Economy Policy Guidebook - Seoul Metropolitan Government

LEMOS, P. (2011): As Universidades de Pesquisa e a Gestão Estratégica do Empreendedorismo Uma proposta de metodologia de análise de ecossistemas, Campinas: Instituto de Geociências - UNICAMP (Ph.D. Thesis).

MONZÓN, J. \& CHAVES, R. (2017): Recent evolutions of the Social Economy in European Union. European Economic and Social Committee and CIRIEC-International, Brussel.

MORAIS, L. (2013): As políticas públicas de Economia Solidária (ESOL): avanços e limites para a inserção sociolaboral dos grupos-problema, Campinas: IE-UNICAMP (Ph.D. Thesis).

MORAIS, L.P. \& BACIC, M.J. (2016): "Redes de Economia Solidária e a relevância do ecossistema empreendedor solidário". V Simpósio Internacional Desigualdades, Direitos e Políticas Públicas e I Conferência Internacional RILESS-EMES: Economia Solidária e Empresas Sociais, UNISINOS.

SERRANO, S. (2015): "Economía social y solidaria: una propuesta para un ecosistema más complejo", Información Estadística y Cartográfica de Andalucía, 5, 172-178.

SILVA, S. (2018): A política de economia solidária no ciclo orçamentário nacional (2004-2018): inserção, expansão e crise de paradigma. Instituto de Pesquisa Econômica Aplicada (IPEA). Texto para Discussão no. 2434.

SPILLING, O. (1996): "The Entrepreneurial system: on entrepreneurship in the context of a megaevent", Journal of Business Research, 36, 91-103.

VUOTTO, M. (2017): "Content and scope of research on cooperatives: the performance of the Latin American Network of researchers on cooperatives", Review of International Co-operation, International Co-operative Alliance, 104, 14-25. 